\title{
Vitamin D metabolism in acute and chronic cholestasis
}

\author{
R. T. JUNG ${ }^{1}$, M. DAVIE, P. Siklos, T. M. CHALMERS, J. O. HUNTER, AND \\ D. E. M. LAWSON \\ From Addenbrooke's Hospital, Cambridge, and Medical Research Council, Dunn Nutrition Unit, \\ Cambridge
}

SUMmARY To study the effects of acute and chronic cholestasis on vitamin D metabolism we investigated six cases of acute extrahepatic obstructive jaundice and eight cases of primary biliary cirrhosis (PBC) (three supplemented with vitamin D). Plasma 25-hydroxyvitamin D (25OHD) was low in the patients with PBC unsupplemented with vitamin D but normal in obstructive jaundice. None of the patients with $\mathrm{PBC}$ showed radiological or histological evidence of osteomalacia. In PBC, dietary intake of vitamin D was low but response to ultra-violet irradiation of the skin was normal even in those with a considerably raised serum bilirubin. Patients with PBC or obstructive jaundice had low levels of 25 hydroxyvitamin $D$ binding protein which correlated with the serum albumin. The half-life of intravenously injected ${ }^{3} \mathrm{H}$ vitamin $\mathrm{D}_{3}\left({ }^{3} \mathrm{HD}_{3}\right)$ and the subsequent production of ${ }^{3} \mathrm{H} 25 \mathrm{OHD}$ were normal in all the patients with obstructive jaundice and in most with PBC. The two patients with $\mathrm{PBC}$ who produced less ${ }^{3} \mathrm{H} 25 \mathrm{OHD}$ than expected were receiving vitamin D supplements. The urinary tritium $\left({ }^{3} \mathrm{H}\right)$ excretion after the injection of ${ }^{3} \mathrm{HD}_{3}$ correlated with the serum bilirubin. After the injection of ${ }^{3} \mathrm{H} 25 \mathrm{OHD}_{3}$ the urinary excretion of ${ }^{3} \mathrm{H}$ was minimal and did not correlate with the serum bilirubin, suggesting that the radioactivity appearing in the urine after the ${ }^{3} \mathrm{H}$ vitamin $\mathrm{D}_{3}$ injection was associated with vitamin $\mathrm{D}$ metabolites other than $25 \mathrm{OHD}$. Factors contributing to the low plasma $250 \mathrm{HD}$ in primary biliary cirrhosis may be a low dietary intake of vitamin $\mathrm{D}$, inadequate exposure to ultra-violet light, and a tendency to urinary wastage of vitamin D metabolites.

Osteomalacia is a well-recognised complication of liver disease especially in those with chronic cholestasis such as primary biliary atresia (PBA) and primary biliary cirrhosis (PBC) (Atkinson et al., 1956; Glasgow et al., 1976). In PBC, low levels of plasma 250HD have been reported (Long et al., 1976; Wagonfeld et al., 1976) but the effect of cholestasis on vitamin D metabolism as distinct from that of hepatocellular dysfunction has yet to be clearly defined. The importance of cholestasis in the development of rickets is well illustrated in PBA where relief of the obstruction results in both a rise in the plasma 25 hydroxycholecalciferol (25OHD) and healing of the rickets, despite the continuing presence of biliary cirrhosis (Daum et al., 1976).

Animal experiments have suggested that

${ }^{1}$ Address for correspondence and reprint requests: Dr R. T. Jung, Addenbrooke's Hospital, Trumpington Street, Cambridge, England.

Received for publication 10 April 1979 cholestasis may affect 25 hydroxylation. Thus 25 hydroxylase activity as measured in rat liver homogenates is reduced by bile duct ligation for 21 days or by the addition of bile salts (Bolt et al., (1978). The finding in patients with PBC of a subnormal rise in plasma $250 \mathrm{HD}$ after the administration of parenteral vitamin $D_{2}$ has suggested an impairment of 25 hydroxylation (Wagonfeld et al., 1976); but a recent tracer study also in patients with PBC has shown no abnormality in the conversion of ${ }^{3} \mathrm{H}$ cholecalciferol $\left({ }^{3} \mathrm{HD}_{3}\right)$ to ${ }^{3} \mathrm{H} 25 \mathrm{OHD}$ (Krawitt $e t$ al., 1977). To investigate further the effect of cholestasis on 25 hydroxylation in man we have studied the metabolism of intravenously injected ${ }^{3} \mathrm{HD}_{3}$ in patients with acute cholestasis due to extrahepatic bile duct obstruction as well as in patients with chronic cholestasis (PBC).

Malabsorption of vitamin D does occur in PBC (Krawitt et al., 1977) but this is unlikely to be a major cause of the low plasma 25OHD in this condition, as ultra-violet light is the more important source of 
vitamin D in man (Preece et al., 1975; Pittet et al., 1979; Poskitt et al., 1979). We have therefore also investigated the response of jaundiced patients with PBC to ultra-violet irradiation.

It has also been reported that the urinary excretion of tritium $\left({ }^{3} \mathrm{H}\right)$ after the injection of ${ }^{3} \mathrm{HD}_{3}$ was increased in jaundiced patients with $\mathrm{PBC}$; preliminary work suggested that this did not represent an increased excretion of 250HD (Krawitt et al., 1977). We have further investigated this possibility by studying the urinary ${ }^{3} \mathrm{H}$ excretion after the injection, on separate occasions, of ${ }^{3} \mathrm{HD}_{3}$ and ${ }^{3} \mathrm{H} 25 \mathrm{OHD}$ in patients with acute and chronic cholestasis.

\section{Methods}

Eight patients with PBC proven by liver biopsy and six patients with acute extrahepatic obstructive jaundice were studied. The patients with PBC were all female, had a mean age of $55.9 \pm 13.7$ years $( \pm$ SD) and had had symptoms for $25.5 \pm 24.1$ months. Three of these patients were receiving supplementary vitamin $D$. The group with acute extrahepatic obstructive jaundice consisted of three male and three female subjects with a mean age of $63 \cdot 8 \pm 9 \cdot 5$ years and had experienced symptoms for $1.0 \pm 1.3$ months. Three had carcinoma of the pancreas and three had gallstones.

All investigations were performed after approval by Addenbrooke's Hospital Ethical Committee and after fully informed consent had been obtained from the patients.

Dietary vitamin D intake was assessed by the recall technique (Burke, 1947). Bone biopsies were obtained from the iliac crest using a trephine needle in six patients with PBC. A bone biopsy was considered normal if there was an osteoid area of less than $5 \%$ with normal calcification fronts (Woods et al., 1968). Serum calcium, phosphate, alkaline phosphatase, bilirubin, and albumin (on $1000 \mathrm{mg}$ calcium diet) were measured by Autoanalyser. Plasma 250HD was measured by a competitive protein binding assay (Edelstein et al., 1974).

25 hydroxyvitamin D binding protein (25OHDBP) was assayed by immunoelectrophoresis using anti-Gc globulin (DAKO). This protein is now believed to be the same as Gc globulin (Bouillon et al., 1976) and the Dako antibody used has been shown to react only against the 25OHDBP (Dann, J. G., personal communication). Vitamin $D_{3}$ halflife and 25OHD production were measured as previously described (Jung et al., 1978). Calcium absorption was measured by a forearm counting technique after seven days on a $10 \mathrm{mmol}(400 \mathrm{mg})$ calcium diet (Chalmers et al., 1973). Urine was collected for 24 hours after the injection of $2.5 \mu \mathrm{C}$ $\left(1,2^{3} \mathrm{H}\right) \mathrm{D}_{3}$ or $2 \cdot 5 \mu \mathrm{C}\left(26,27^{3} \mathrm{H}\right) 25 \mathrm{OHD}_{3} .1 \mathrm{ml}$ samples were treated with $(5-14 \%)$ sodium hypochlorite (BDH) to reduce quenching. This process was shown not to reduce counts due to ${ }^{3} \mathrm{H}$. The aqueous solution was counted in a Triton/PPO/ POPOP scintillator in a Packard 2425 liquid scintillation counter.

Response to ultra-violet light was assessed in four female control subjects and three patients with PBC. A total of 20 minutes' whole body exposure was given over four weeks using four Westinghouse FS40 lamps. One patient (see Table 2, PBC subject 3) aged 65 with Stage IV PBC (Scheuer, 1973) was studied in detail during ultra-violet light exposure with ${ }^{3} \mathrm{HD}_{3}$ half-life measurements before and after ultra-violet irradiation.

\section{Results}

BIOCHEMICAL FINDINGS

Table 1 shows the biochemical findings in the patients with PBC and extrahepatic obstructive

Table 1 Biochemical data

\begin{tabular}{|c|c|c|c|c|}
\hline \multirow[t]{2}{*}{ Biochemical tests } & \multicolumn{2}{|c|}{ Primary biliary cirrhosis } & \multirow{2}{*}{$\begin{array}{l}\text { Extrahepatic obstructive } \\
\text { jaundice }\end{array}$} & \multirow[t]{2}{*}{ Normal range } \\
\hline & $\begin{array}{l}\text { Non-Vitamin D } \\
\text { supplemented } \\
(5)\end{array}$ & $\begin{array}{l}\text { Vitamin D2 } \\
\text { supplemented } \\
(3)\end{array}$ & & \\
\hline $\begin{array}{l}\text { Plasma } \\
\text { Calcium (mmo1/1) } \\
\text { Phosphate (mmo1/1) } \\
\text { Alkaline phosphatase (IU/1) } \\
\text { Albumin }(\mathrm{g} / 1) \\
\text { Bilirubin }(\mu \mathrm{mol} / 1) \\
\text { 25OHD (nmo1/1) } \\
\text { 25OHD binding protein }(\mu \mathrm{g} / \mathrm{m} 1)\end{array}$ & $\begin{aligned} 2.23 & \pm 0.20 \\
1.08 & \pm 0.14 \\
875 & \pm 462 \\
34 & \pm 6.2 \\
161.4 & \pm 169.1 \\
13 & \pm 11 \cdot 3 \\
223 & \pm 54\end{aligned}$ & $\begin{array}{rl}2 \cdot 18 & 0.16 \\
1 \cdot 17 & \pm 0 \cdot 12 \\
867 & \pm 711 \\
32 & \pm 3 \cdot 5 \\
143 \cdot 7 & \pm 187 \cdot 4 \\
26 \cdot 3 & \pm 8 \cdot 3 \\
199 \cdot 5 & \pm 24 \cdot 7\end{array}$ & $\begin{aligned} 2 \cdot 16 & \pm 0 \cdot 11 \\
1 \cdot 20 & \pm 0 \cdot 12 \\
652 & \pm 698 \\
33 \cdot 5 & \pm 7 \cdot 7 \\
161 \cdot 5 & \pm 105 \cdot 8 \\
21 & \pm 12 \cdot 3 \\
235 & \pm 17\end{aligned}$ & $\begin{array}{c}2.0-2.6 \\
0.8-1.4 \\
30-92 \\
35-53 \\
2-14 \\
26 \pm 9.5 \\
300-550\end{array}$ \\
\hline
\end{tabular}

Mean \pm SD.

Number of patients in parentheses.

Calcium: $1 \mathrm{mmo1} / 1=0.25 \times \mathrm{mg} / 100 \mathrm{ml}$. Phosphate: $1 \mathrm{mmol} / 1=0.323 \times \mathrm{mg} / 100 \mathrm{ml}$.

Bilirubin : $1 \mu \mathrm{mol} / 1=17 \cdot 1 \times \mathrm{mg} / 100 \mathrm{ml}$. 25OHD: $1 \mathrm{nmol} / 1=400 \mathrm{ng} / 1$. 
jaundice. Plasma 250HD was significantly lower in the patients with $\mathrm{PBC}$ not receiving supplementary vitamin $D$ compared with the controls $(P<0.05)$. In the patients with extrahepatic obstructive jaundice and those with $\mathrm{PBC}$ receiving supplementary vitamin $\mathrm{D}$, the plasma 25OHD levels were similar to those of controls. Plasma 250HD failed to correlate with the serum albumin, serum bilirubin, or duration of symptoms in PBC, although the latter did correlate with the serum bilirubin $(r=0.73$, $P<0.05$ ).

Low plasma 25OHDBP was found both in PBC and obstructive jaundice. There was a significant correlation of the plasma 25OHDBP with the serum albumin $(r=0.78, \mathrm{P}<0.01)$, but no correlation between plasma 25OHDBP and plasma 25OHD or ${ }^{3} \mathrm{H}$ vitamin D half-life.

\section{INTAKE OF VITAMIN D AND ABSORPTION}

\section{OF CALCIUM}

Dietary intake of vitamin $D$ in the patients with PBC was low at $40 \pm 24 \mathrm{IU} /$ day (recommended intake $100 \mathrm{IU} /$ day). ${ }^{47} \mathrm{Ca}$ absorption was low in all patients with $\mathrm{PBC}(26 \cdot 0 \pm 9 \cdot 8 \%$, n.r. $25-72 \%)$ with no significant difference between those having vitamin D supplements and those not. No correlation was found between the plasma 25OHD and ${ }^{47} \mathrm{Ca}$ absorption.

\section{BONE MORPHOLOGY}

Patients with PBC showed no evidence of osteomalacia or hyperparathyroidism on iliac crest biopsy and radiology showed no Looser's zones or any new or old fractures.

\footnotetext{
${ }^{3}$ H VITAMIN D STUDIES

Previous studies have shown that in a normal population there is a negative correlation between the ${ }^{3} \mathrm{HD}_{3}$ clearance from plasma and the plasma 25OHD (Jung et al., 1978). In the patients with acute obstruction, the ${ }^{3} \mathrm{HD}_{3}$ half-life was appropriate to the plasma 25OHD level. Most of the patients with PBC also had an appropriate response, but two subjects, both with very low plasma 25OHD levels, had a ${ }^{3} \mathrm{HD}_{3}$ half-life longer than expected. The appearance of ${ }^{3} \mathrm{H} 25 \mathrm{OHD}$ in the plasma four hours after the injection of ${ }^{3} \mathrm{HD}_{3}$ was also measured (Fig. 1) and in normal subjects a negative correlation exists between this and the vitamin ${ }^{3} \mathrm{HD}_{3}$ half-life $(r=-0.68)$ (Jung et al., 1978). All the patients with acute obstruction had a normal response, as did the majority of patients with PBC. Two patients with PBC produced less ${ }^{3} \mathrm{H}$ 25OHD than expected. Both were on supplementary vitamin $\mathbf{D}$ and had normal vitamin D half-lives.
}

Urinary ${ }^{3} \mathrm{H}$ was counted after the injection of
${ }^{3} \mathrm{HD}_{3}$ in six patients with $\mathrm{PBC}$ and one with extrahepatic obstructive jaundice (Fig. 2). A positive correlation was found between serum bilirubin and urinary ${ }^{3} \mathrm{H}(r=0.8 ; \mathrm{P}<0.02)$. At normal levels of serum bilirubin very little radioactivity appeared in the urine and it was only at a serum bilirubin level of $30 \mu \mathrm{mol} / 1$ that urinary ${ }^{3} \mathrm{H}$ rose above $1 \%$ of the injected dose. In these patients urinary ${ }^{3} \mathrm{H}$ was strongly correlated with ${ }^{3} \mathrm{HD}_{3}$ half-life $(r=0 \cdot 86$, $P<0.01$ ). No relationship was found between urinary ${ }^{3} \mathrm{H}$ and serum albumin.

\section{${ }^{3} \mathrm{H}^{25 \mathrm{OHD}_{3}}$ STUDIES}

After ${ }^{3} \mathrm{H} 25 \mathrm{OHD}_{3}$ was injected intravenously very little ${ }^{3} \mathrm{H}$ appeared in the urine and there was no correlation with the serum bilirubin (Fig. 2). Most patients excreted less than $3 \%$ of the injected dose of ${ }^{3} \mathrm{H} 25 \mathrm{OHD}_{3}$ but two people with serum bilirubins of 145 and $62 \mu \mathrm{mol} / \mathrm{l}(8.5$ and $3.6 \mathrm{mg} / 100 \mathrm{ml})$ excreted $4.5 \%$ and $3.6 \%$ respectively.

\section{ULTRA-VIOLET LIGHT}

The response to ultra-violet light was examined in three patients with PBC (Table 2), two with severe jaundice and one with a slightly raised bilirubin. All three patients demonstrated a rise of plasma 25OHD similar to that seen in four normal subjects, the greatest rise occurring in the patient with the lowest initial plasma 25OHD level. This patient was studied in detail (Fig. 3). Bone biopsy showed no evidence of osteomalacia. The serum calcium was $1.98 \mathrm{mmol} / \mathrm{l}$ $(7.9 \mathrm{mg} / 100 \mathrm{ml})$ albumin $25 \mathrm{~g} / \mathrm{l}$, phosphate 0.85 $\mathrm{mmol} / 1 \mathrm{l}(2.6 \mathrm{mg} / 100 \mathrm{ml})$, bilirubin $116 \mu \mathrm{mol} / \mathrm{l}(6 \cdot 8$ $\mathrm{mg} / 100 \mathrm{ml}$ ), alkaline phosphatase $148 \mathrm{IU} / \mathrm{l}$, and plasma $25 \mathrm{OHD} 4.3 \mathrm{nmol} / \mathrm{l}(1.7 \mu \mathrm{g} / \mathrm{l})$. The plasma 250HD level rose rapidly after starting ultra-violet therapy and was accompanied by a rise in serum calcium, phosphate, and alkaline phosphatase. ${ }^{3} \mathrm{H}$ vitamin D half-life was 15.0 hours initially and rose to

Table 2 Response of plasma 25 hydroxycholecalciferol to ultra-violet irradiation

\begin{tabular}{llll}
\hline Patients & \multicolumn{2}{l}{$25 \mathrm{HD}(\mathrm{nmol} / \mathrm{l})$} & $\begin{array}{c}\text { Bilirubin } \\
(\mu \mathrm{mol} / 1)\end{array}$ \\
\cline { 2 - 3 } & \multicolumn{2}{c}{ Ultra-violet light } & \\
\cline { 2 - 3 } & Before & After & \\
\hline Controls & 27 & & Normal \\
1 & $33 \cdot 3$ & $43 \cdot 8$ & \\
2 & $26 \cdot 3$ & 85 & \\
3 & $18 \cdot 8$ & $45 \cdot 5$ & \\
4 & & 34 & 32 \\
Primary biliary & & & 410 \\
cirrhosis & $28 \cdot 5$ & 36 & 116 \\
1 & 28 & $38 \cdot 3$ & \\
2 & $4 \cdot 3$ & $37 \cdot 5$ & \\
3 & & & \\
\hline
\end{tabular}




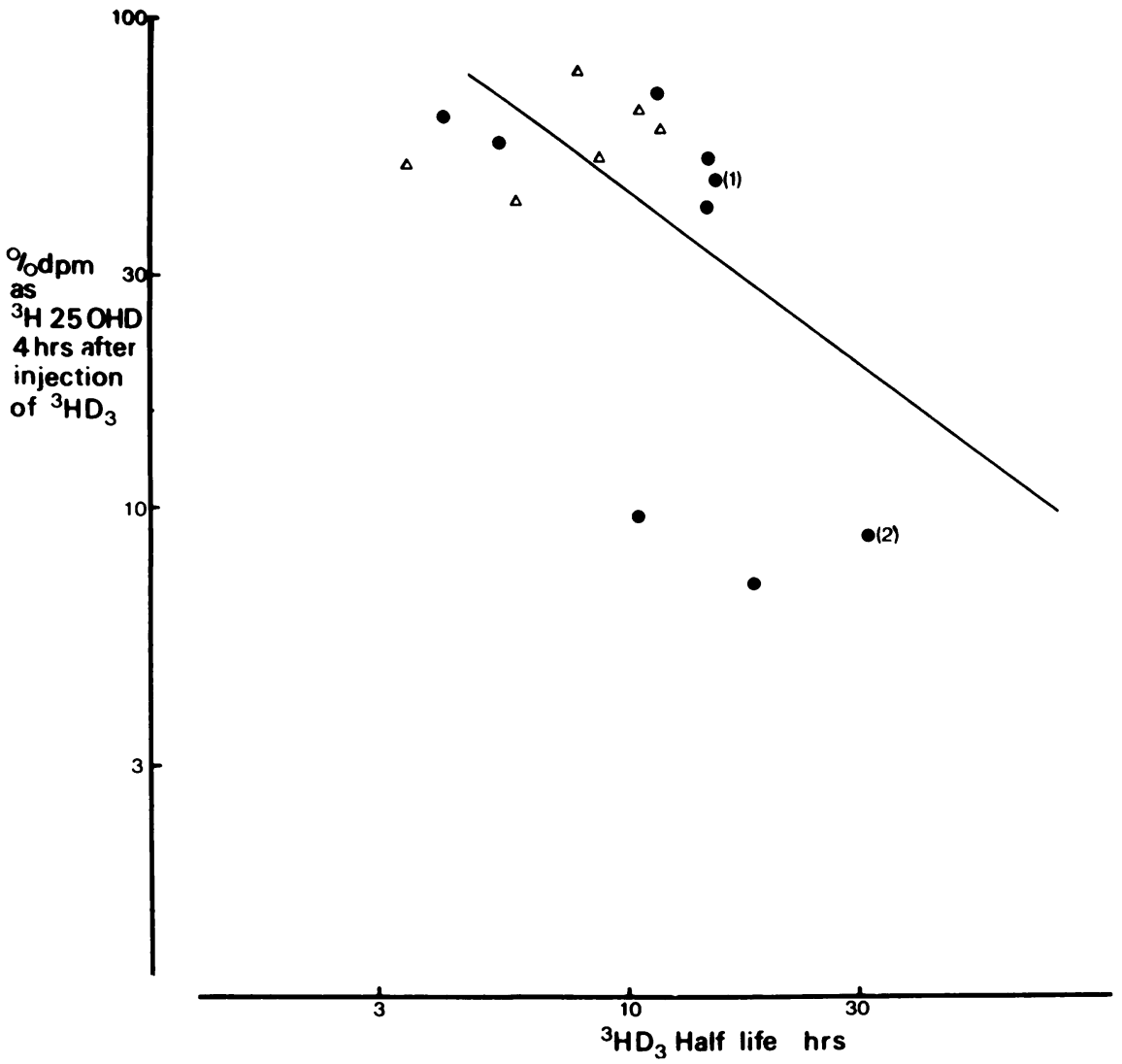

Fig. 1 Relationship of the percentage dpm in plasma as ${ }^{3} \mathrm{H} 250 \mathrm{HD}$ at four hours after an intravenous injection of ${ }^{3} \mathrm{H}$ cholecalciferol and ${ }^{3} \mathrm{H}$ cholecalciferol half-life in patients with acute obstructive jaundice $(\triangle)$ and primary biliary cirrhosis $(\bullet)$. The regression line for normal subjects is shown $(r=-0.68, \mathrm{P}<0.01)$. (1) and (2) represent the values in a patient with primary biliary cirrhosis before and after exposure to ultra-violet light (see also Fig. 3).

Table 3 Incidence of osteomalacia on bone biopsy in reported series of primary biliary cirrhosis

\begin{tabular}{|c|c|c|c|c|}
\hline & \multicolumn{3}{|c|}{ Primary biliary cirrhosis } & \multirow[t]{3}{*}{ Histological criteria for osteomalacia } \\
\hline & \multirow[t]{2}{*}{$\begin{array}{l}\text { Cases } \\
\text { (no.) }\end{array}$} & \multicolumn{2}{|l|}{$\begin{array}{l}\text { With } \\
\text { osteomalacia }\end{array}$} & \\
\hline & & (no.) & $(\%)$ & \\
\hline Atkinson et al. (1956) & 12 & 4 & 33 & Osteoid width \\
\hline Kehayoglou et al. (1968) & 12 & 1 & $8 \cdot 3$ & Osteoid area $>3 \cdot 2 \%$ \\
\hline Ajdukiewicz et al. (1974) & 14 & 2 & $14 \cdot 3$ & $\begin{array}{l}\text { Osteoid }>30 \% \text { of surface or more than } 1 \% \\
\text { of section area }\end{array}$ \\
\hline Long et al. (1978a) & 20 & 15 & 75 & Osteoid $>0.5 \%$ \\
\hline Reed et al. (1977) & 6 & & 83 & Fractional osteoid surface \\
\hline Compston et al. (1977) & 11 & $\begin{array}{l}4 \\
\text { (all on chole- }\end{array}$ & $36 \cdot 4$ & $\begin{array}{l}\text { Increased volume and surface area of } \\
\text { osteoid }\end{array}$ \\
\hline $\begin{array}{l}\text { Compston et al. (1978) } \\
\text { (personal communication) }\end{array}$ & 30 & 3 & 10 & Osteoid area and calcification front \\
\hline $\begin{array}{l}\text { Jung et al. (to date) } \\
\text { Total }\end{array}$ & $\begin{array}{r}6 \\
111\end{array}$ & $\begin{array}{r}0 \\
34\end{array}$ & $\stackrel{0}{30 \cdot 6 \%}$ & Osteoid area $>5 \%$ \\
\hline
\end{tabular}




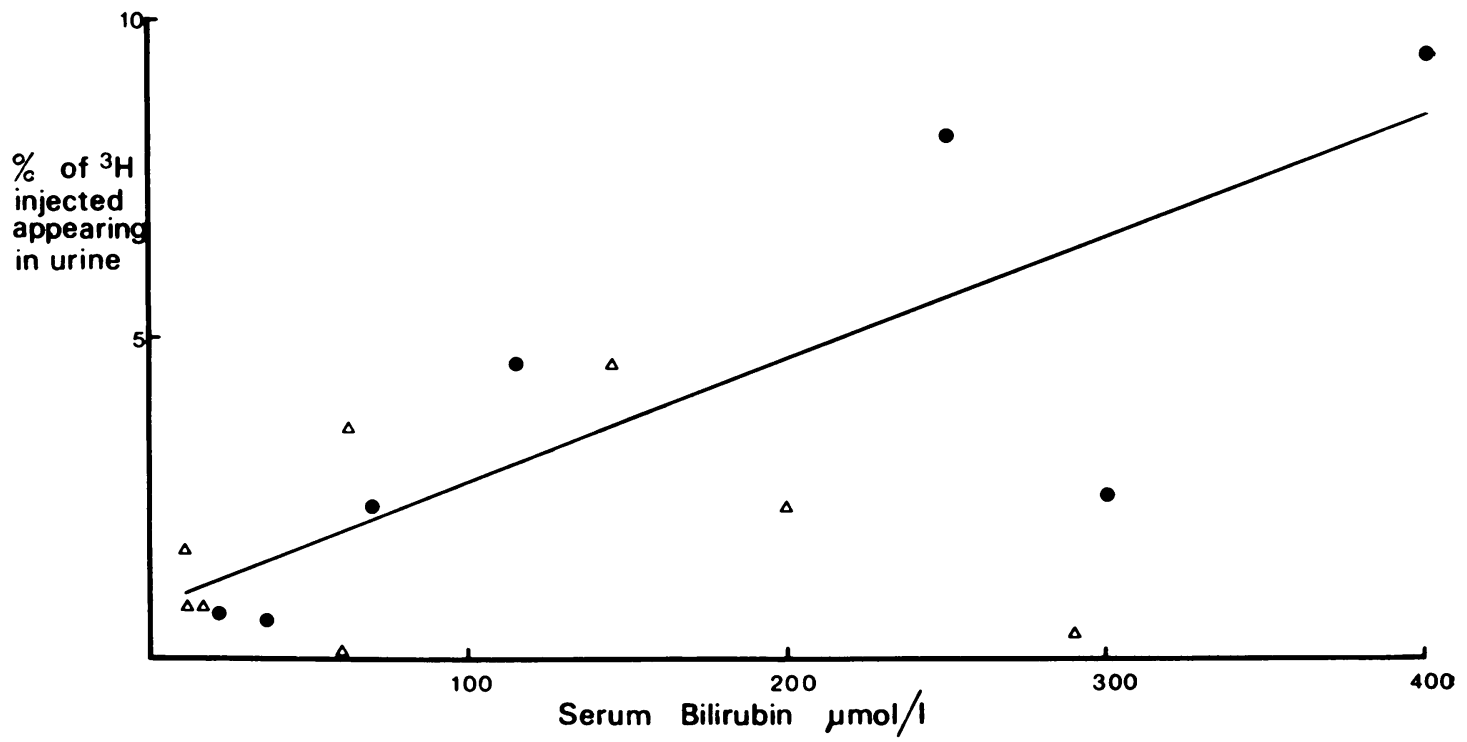

Fig. 2 The urinary excretion of radioactivity as a function of the serum bilirubin in patients with primary biliary cirrhosis and acute obstructive jaundice after an intravenous injection of ${ }^{3} \mathrm{H}$ cholecalciferol $(0)$ or ${ }^{3} \mathrm{H} 25$ hydroxycholecalciferol $(\triangle)$. The regression line of the urinary excretion of radioactivity after the injection of ${ }^{3} \mathrm{H}$ cholecalciferol $(r=0 \cdot 8)$ is shown.

30 hours after therapy. The percentage of ${ }^{3} \mathrm{H} 25 \mathrm{OHD}$ appearing at four hours after the injection of ${ }^{3} \mathrm{HD}_{3}$ was $46.7 \%$ before ultra-violet light and $8.9 \%$ after treatment; a similar response to that seen in normal subjects before and after exposure to ultra-violet light.

\section{Discussion}

Despite the low levels of plasma 250HD in our patients with PBC none showed evidence of osteomalacia on bone histology or radiology. This contrasts with other reports in which the incidence of osteomalacia in PBC has varied from 8 to $83 \%$ $($ mean $=30.6 \%)$ (Table 3$)$. This wide variation in incidence may be due to the different histological criteria used for the diagnosis of osteomalacia. As osteoid increases with age (Bordier and Tun Chot, 1972), care must be taken in interpreting the osteoid measurements, as in most reported series the mean age of the patients with PBC was over 50 years.

The present work demonstrates that ${ }^{3} \mathrm{H}$ 25OHD production from injected ${ }^{3} \mathrm{HD}_{3}$ is normal in all patients with acute obstructive jaundice and the majority of patients with PBC. Although this observation confirms a previous report of normal 25 hydroxylation in PBC (Krawitt et al., 1977), it is at variance with the finding of a $48 \%$ reduction in 25 hydroxylase activity in liver homogenates from rats in which the bile duct had been ligated for 21 days (Bolt et al., 1978). This difference may well represent species variation. We found normal 25 hydroxylation in two patients with acute bile duct obstruction who had serum bilirubin levels of 300 and $360 \mu \mathrm{mol} / 1$. Moreover, in PBC plasma 25OHD was not correlated with biochemical indices of hepatic function. The low $250 \mathrm{OH}$ production found in two patients with PBC could indicate an impairment of 25 hydroxylation due to liver disease. An alternative explanation, as both were receiving supplementary vitamin $D$, is that it was due to a forward negative effect of a high liver vitamin D level on 25 hydroxylation (Mawer et al., 1977).

The fact that acute cholestasis does not result in a rapid reduction in the plasma 25OHD suggests that the reduced plasma 25OHD in PBC is related to the duration of cholestasis rather than to the severity of liver damage. It is unlikely that the low level of 25OHDBP found in patients with acute and chronic cholestasis is a cause of low plasma 25OHD as this binding protein is only $2-3 \%$ saturated in normal subjects and thus has a considerable reserve of binding capacity even in a reduced concentration (Haddad and Walgate, 1976).

We have confirmed the finding that the urinary excretion of ${ }^{3} \mathrm{H}$ after the injection of ${ }^{3} \mathrm{HD}_{3}$ in PBC correlates with the serum bilirubin (Krawitt et al., 1977). We also found a similar relationship in acute 

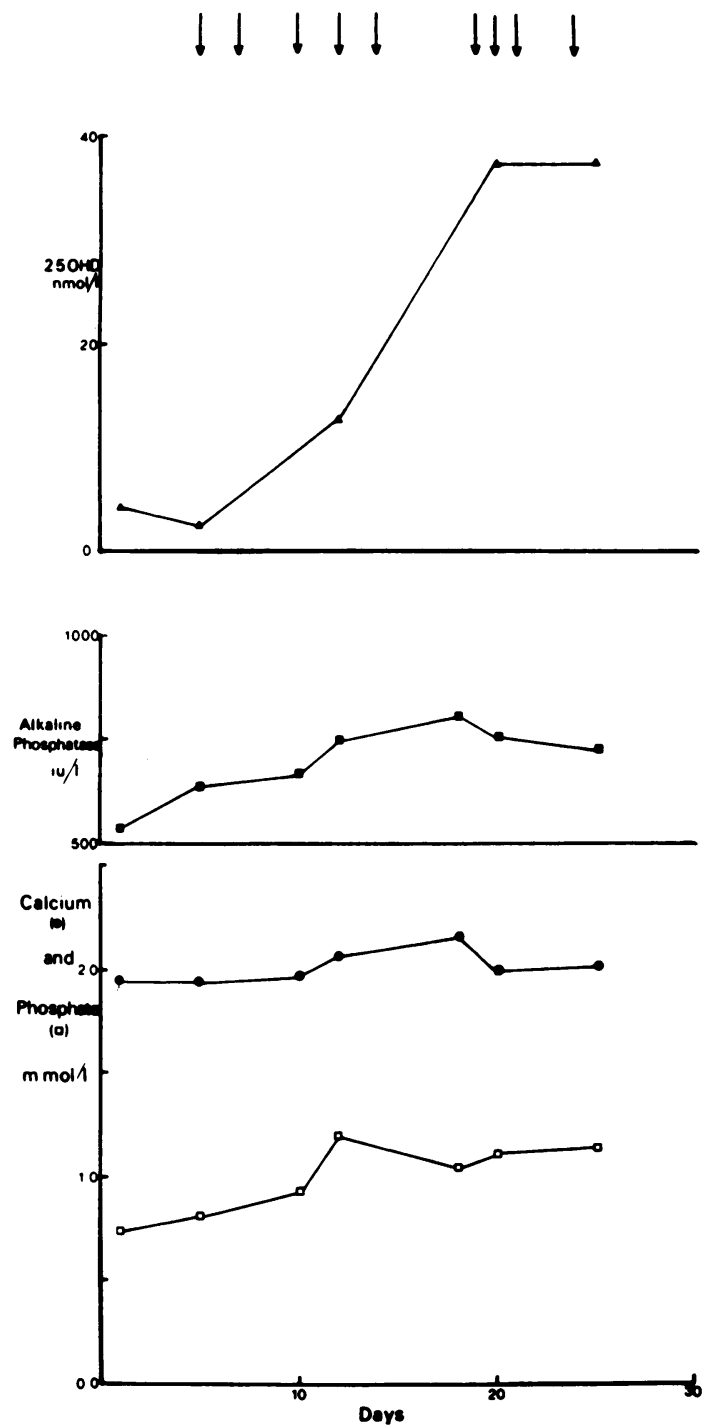

Fig. 3 The biochemical response to ultra-violet light in a patient with primary biliary cirrhosis. The arrows indicate the days on which ultra-violet light was administered.

cholestasis. It is possible that this urinary radioactivity represents water soluble metabolites which would normally be excreted in bile in subjects with intact biliary drainage. There is evidence for biliary excretion of vitamin D metabolites in normal man. Arnaud et al. (1975) found after intravenous injection of ${ }^{14} \mathrm{CD}_{3}$ that up to $10 \%$ of the radioactivity could be recovered from duodenal aspirates within six hours.

After injection of ${ }^{3} \mathrm{H} 25 \mathrm{OHD}_{3}$, we found that very little radioactivity appeared in the urine even at high serum bilirubin concentrations and there was no correlation with the serum bilirubin. This suggests that the radioactivity excreted in urine after ${ }^{3} \mathrm{HD}_{3}$ injection represents metabolites of vitamin $\mathrm{D}$, other than 250HD. This urinary radioactivity may represent metabolites normally produced in the liver and excreted in the bile, or an abnormal metabolism of vitamin D resulting in the increased formation of abnormal water soluble metabolites. These urinary losses in cholestasis could deplete body stores of vitamin $D$, if vitamin $D$ input were inadequate or borderline. The lack of any appreciable urinary excretion of radioactivity after an injection of ${ }^{3} \mathbf{H}$ $25 \mathrm{OHD}_{3}$ even in severe cholestasis would tend to imply that very little $250 \mathrm{HD}$ is normally excreted in the bile in a water soluble form. Nevertheless, Arnaud et al. (1975) have reported that, in man, after an injection of $\left(26-27^{3} \mathrm{H}\right) 25 \mathrm{OHD}$, a third of the radioactivity appeared in duodenal aspirates within 24 hours. Results suggestive of an enterohepatic circulation of 250HD have been found in rats (Sitrin et al., 1978) and rhesus monkeys (Rikkers, 1975). However, additional work is necessary to characterise the nature of the radioactivity appearing in bile after ${ }^{3} \mathrm{H} 25 \mathrm{OHD}_{3}$ injection and the significance of a possible enterohepatic circulation of $250 H D$ in man.

As the plasma clearance and hydroxylation of ${ }^{3} \mathrm{HD}_{3}$ is normal, the low plasma $250 \mathrm{OD}$ of chronic cholestasis may be due to a reduction in the input of vitamin $\mathrm{D}$. We did find dietary intake of vitamin $\mathbf{D}$ to be low in PBC and absorption of vitamin D is likely to have been impaired in the presence of steatorrhoea (mean faecal fat was $54.8 \pm 6.9$ mmol per 24 hours). However, this low dietary intake would be important only if exposure or response to ultra-violet light were reduced, as the major source of vitamin D in man is ultra-violet irradiation. It has recently been shown that the ingestion of $200 \mathrm{IU}$ of vitamin $D_{2}$ per day for one month did not raise the plasma 25OHD significantly, whereas irradiation of $600 \mathrm{~cm}^{2}$ of skin for five minutes produced a significant increase in the plasma 25OHD (Poskitt et al., 1979; Davie and Lawson, in preparation). Also, plasma 25OHD has been shown to be significantly reduced in sailors submerged in nuclear submarines for several months despite adequate dietary intake of vitamin D (Preece et al., 1975). Fractionation studies on plasma $250 \mathrm{HD}$ have shown that $84 \%$ of the total plasma $250 \mathrm{HD}$ is $25 \mathrm{OHD}_{3}$, presumably derived mostly from sunlight (Haddad and Hahn, 1973).

We found a normal response to ultra-violet light in the three patients with BPC, despite a considerably raised serum bilirubin in two of the subjects. In the 
patient studied in detail, where the serum bilirubin was $116 \mu \mathrm{mol} / 1(6.8 \mathrm{mg} / 100 \mathrm{ml})$, the rise in serum calcium and phosphate as well as in plasma 25OHD suggested a low vitamin $D$ reserve, although the bone biopsy showed no evidence of osteomalacia. ${ }^{3} \mathrm{H}$ 25OHD production from injected ${ }^{3} \mathrm{HD}_{3}$ diminished appropriately as the plasma $25 \mathrm{OHD}$ rose and ${ }^{3} \mathrm{HD}_{3}$ half-life became longer, again emphasising the normal 25 hydroxylation in $\mathrm{PBC}$, even though the initial plasma 250HD was low in this patient. The adequate response to ultra-violet light in these three patients suggests that the low 25OHD in PBC is due to inadequate exposure to sunlight. We have no evidence that jaundice may raise the threshold of response to ultra-violet light but this possibility will need to be excluded by further quantitative studies.

We conclude that, in acute and chronic cholestasis, 25 hydroxylation is normal but ${ }^{3} \mathrm{H}$ excretion in urine is increased after injection of ${ }^{3} \mathrm{HD}_{3}$. Increased excretion of vitamin D metabolites may be sufficient to deplete vitamin $\mathbf{D}$ reserves if input is inadequate. Although oral intake and absorption of vitamin D are low in PBC, input from the skin should be sufficient to maintain reserves (as the response to ultra-violet light is normal) unless exposure to sunlight is also inadequate. It is likely, therefore, that the development of osteomalacia in PBC is multifactorial. As $25-$ and $1 \alpha$-hydroxylation (Long et al., 1978b) are normal, parenteral vitamin D or ultra-violet light should prevent osteomalacia in all cases.

\section{Addendum}

Since this manuscript was submitted for publication we have measured the urinary excretion of radioactivity after intravenous ${ }^{3} \mathrm{H} 25 \mathrm{OHD}_{3}$ in an additional five jaundiced patients with acute biliary obstruction (two with complete obstruction). We have confirmed that very little radioactivity (less than $3 \%$ ) appears in the urine even at serum bilirubin concentration as high as $200 \mu \mathrm{mol} / \mathrm{l}(11.7 \mathrm{mg} / 100 \mathrm{ml})$.

We thank all our volunteers for their co-operation and Mrs M. Shorthouse for technical assistance, and Dr D. G. D. Wight for reporting on the bone biopsies.

\section{References}

Ajdukiewicz, A. B., Agnew, J. E., Byers, P. D., Wills, M. R., and Sherlock, S. (1974). The relief of bone pain in primary biliary cirrhosis with calcium infusions. Gut, 15, 788-793.

Arnaud, S. B., Goldsmith, R. S., Lambert, P. W., and Go, V. L. W. (1975). 25-hydroxyvitamin $D_{3}$ : evidence of an entero-hepatic circulation in man. Proceedings of the
Society for Experimental Biology and Medicine, 149, 570-572.

Atkinson, M., Nordin, B. E. C., and Sherlock, S. (1956). Malabsorption and bone disease in prolonged obstructive jaundice. Quarterly Journal of Medicine, 25, 299-312.

Bolt, M., Sitrin, M., Favus, M., and Rosenberg, I. H. (1977). Hepatic vitamin D 25 hydroxylase: inhibition by bile duct ligation or bile salts in vitro. Clinical Research, 25, 606A.

Bordier, P. J., and Tun Chot, S. (1972). Quantitative histology of metabolic bone disease. Clinics in Endocrinology and Metabolism, 1, 197-215.

Bouillon, R., Van Baelen, H., Rombauts, W., and De Moor, P. (1976). The purification and characterisation of the human serum binding protein for the 25 -hydroxycholecalciferol (Transcalciferin). Identity with group-specific component. European Journal of Biochemistry, 66, 285-291.

Burke, B. S. (1947). The dietary history as a tool in research. Journal of American Dietetic Association, 23, 1041-1048.

Chalmers, T. M., Davie, M. W., Hunter, J. O., Szaz, K. F., Pelc, B., and Kodicek, E. (1973). 1-alpha-hydroxycholecalciferol as a substitute for the kidney hormone 1,25 dihydroxycholecalciferol in chronic renal failure. Lancet, 2, 696-699.

Compston, J. E., Crowe, J., Wells, I., Horton, L. W. L., Herst, D., Merrett, A. L., Woodhead, J. S., and Williams, R. (1978). Vitamin D prophylaxis and osteomalacia in chronic cholestasis (Abstract). Gut, 19, A984.

Compston, J. E., and Thompson, R. P. H. (1977). Intestinal absorption of 25 -hydroxyvitamin $D$ and osteomalacia in primary biliary cirrhosis. Lancet, 1, 721-724.

Daum, F., Rosen, J. F., Roginsky, M., Cohen, M. I., and Finberg, L. (1976). 25-hydroxycholecalciferol in the management of rickets associated with extrahepatic biliary atresia. Journal of Paediatrics, 88, 1041-1043.

Edelstein, S., Charman, M., Lawson, D. E. M., and Kodicek E. (1974). Competitive protein-binding assay for 25 hydroxycholecalciferol. Clinical Science and Molecular Medicine, 46, 231-240.

Glasgow, J. F. T., and Thomas, P. S. (1976). The osteodystrophy of prolonged obstructive liver disease in childhood. Acta Paediatrica Scandinavica, 65, 57-64.

Haddad, J. G., Jr, and Hahn, T. J. (1973). Natural and synthetic sources of circulating 25 -hydroxyvitamin $D$ in man. Nature, 244, 515-517.

Haddad, J. G., Jr, and Walgate, J. (1976). Radioimmunoassay of the binding protein for vitamin $\mathrm{D}$ and its metabolites in human serum: concentrations in normal subjects and patients with disorders of mineral homeostasis. Journal of Clinical Investigation, 58, 1217-1222.

Jung, R. T., Davie, M., Hunter, J. O., Chalmers, T. M., and Lawson, D. E. M. (1978). Abnormal vitamin D metabolism in cirrhosis. Gut, 19, 290-293.

Kehayoglou, A. K., Holdsworth, C. D., Agnew, J. E., Whelton, M. J., and Sherlock, S. (1968). Bone disease and calcium absorption in primary biliary cirrhosis. Lancet, 1 , 715-719.

Krawitt, E. L., Grundman, M. J., and Mawer, E. B. (1977). Absorption, hydroxylation, and excretion of vitamin Din primary biliary cirrhosis. Lancet, 2, 1246-1249.

Long, R. G., Meinhard, E., Skinner, R. K., Varghese, Z., Wills, M. R., and Sherlock, S. (1978a). Clinical, biochemical, and histological studies of osteomalacia, osteoporosis, and parathyroid function in chronic liver disease. Gut, 19, 85-90.

Long, R. G., Skinner, R. K., Wills, M. R., and Sherlock, S. (1976). Serum 25-hydroxy-vitamin D in untreated parenchymal and cholestatic liver disease. Lancet, 2, 650-652. 
Long, R. G., Skinner, R. K., Wills, M. R., and Sherlock, S. (1978b). Formation of vitamin D metabolites from ${ }^{3} \mathrm{H}$ and ${ }^{14} \mathrm{C}$ radiolabelled vitamin $\mathrm{D}^{3}$ in chronic liver diseases. Clinica Chimica Acta, 85, 311-317.

Mawer, E. B., and Reeve, A. (1977). The use of an isolated perfused liver to study the control of cholecalciferol-25hydroxylase activity in the rat. Calcified Tissue Research, suppl 22, 24-28.

Pittet, P. G., Davie, M., and Lawson, D. E. M. (1979). Aspects of the development of osteomalacia in the elderly. Nutrition and Metabolism, 23, 109-116.

Poskitt, E. M. E., Cole, T. J., and Lawson, D. E. M. (1979). Diet, sunlight, and 25 hydroxyvitamin $D$ in healthy children and adults. British Medical Journal, 1, 221-223.

Preece, M. A., Tomlinson, S., Ribot, C. A., Pietrek, J., Korn, H. T., Davies, D. M., Ford, J. A., Dunnigan, M. G., and O'Riordan, J. L. H. (1975). Studies of vitamin D deficiency in man. Quarterly Journal of Medicine, 44, 575-589.

Reed, J. S., Meredith, S. C., Nemchausky, B. A., Rosenberg, I. H., and Boyer, J. L. (1977). Assessment of morphologic response to $25-\mathrm{OH}$ vitamin (25-OH-D) therapy in patients with primary biliary cirrhosis (Abstract). Gastroenterology, 72, A158.

Rikkers, H. (1975). Excretory products of ${ }^{3} \mathrm{H}$-vitamin $\mathrm{D}_{3}$ in the newborn rhesus monkey: evidence for intestinal reabsorption of 25-hydroxy vitamin $\mathrm{D}_{3}$. Clinical Research, 23, 328A.

Scheuer, P. J. (1973). Liver Biopsy Interpretation, p. 37. Baillière Tindall: London.

Sitrin, M., Bolt, M., and Rosenberg, I. H. (1978). Characterization and quantitative analysis of the biliary excretion products of vitamin D and 25-OH-vitamin D (25-OH-D). Clinical Research, 26, 285A.

Wagonfeld, J. B., Nemchausky, B. A., Bolt, M., Horst, J. V., Boyer, J. L., and Rosenberg, I. H. (1976). Comparison of vitamin D and 25-hydroxy-vitamin D in the therapy of primary biliary cirrhosis. Lancet, 2, 391-394

Woods, C. G., Morgan, D. B., Paterson, C. R., and Gossmann, H. H. (1968). Measurement of osteoid in bone biopsy. Journal of Pathology and Bacteriology, 95, 441-447. 